\title{
Degradation Assessment of a Photovoltaic Plant After Several Years of Operation
}

\author{
Hawa Diatara Ndiath ${ }^{1,2, *}$, Pierre Williams Tavarez ${ }^{1,2}$, Serigne Thiao ${ }^{1,2}$, Awa Mar ${ }^{1,2}$, \\ Amadou Tidiane Niang ${ }^{2}$, Babacar Mbow ${ }^{1}$, Issakha Youm ${ }^{1,2}$ \\ ${ }^{1}$ Department of Physics, Faculty of Science and Technology, Dakar, Senegal \\ ${ }^{2}$ Center of Studies and Researches on Renewable Energy CERER BP Dakar-Hann / UCAD, Dakar, Senegal
}

\section{Email address:}

evadiatara@hotmail.fr (H. D. Ndiath)

${ }^{*}$ Corresponding author

\section{To cite this article:}

Hawa Diatara Ndiath, Pierre Williams Tavarez, Serigne Thiao, Awa Mar, Amadou Tidiane Niang, Babacar Mbow, Issakha Youm. Degradation Assessment of a Photovoltaic Plant After Several Years of Operation. Science Journal of Energy Engineering. Vol. 6, No. 1, 2018, pp. 1-7. doi: 10.11648/j.sjee.20180601.11

Received: February 2, 2018; Accepted: February 27, 2018; Published: March 28, 2018

\begin{abstract}
This present study is an evaluation of the degradation of the electric characteristics of the photovoltaic modules of a solar power plant settled in the CERER after 3.3 years of operation. The Center of Studies and Researches on Renewable energy is an institute of Cheikh Anta Diop University of Dakar. It is situated in the district of Hann Bel Air. Since a few years; the CERER contributed a lot research of solutions to the problems of development bound to the energy and to the environment it is all the interest of this evaluation which aims at the improvement and at the planning of the photovoltaic systems. It is what explains the study of this evaluation which was proposed. Moreover the evaluation of the degradation of the solar power plant is centered on the global system, constituted by 18 polycristallins, all identical modules of type STP175P-1, connected in series. So we calculated the rates of degradation of the electric characteristics of modules after a few years of operation such as the characteristics I-V and P-V, the maximal power (Pmax), the maximal tension (Vmax), the maximal current (Imax), the tension in opened circuit (Voc), the current of short circuit (Icc) and the fill factor (FF) in the standard conditions of test (STC). The study of this global system allowed to take up respectively the rates of annual degradation of $2.01 \%$ / year, $1.69 \%$ / year, $0.34 \%$ / year, $1.1 \%$ / year and $0.9 \%$ / year for the power, the maximal tension, the maximal current, the current of short circuit, the tension in open circuit and the factor (mailman) of shape. We observed that the most degraded performances are: the maximal power, the maximal current, the current of short circuit and the fill factor; while the tension with open circuit shows no significant degradation during these 3.3 years of operation.
\end{abstract}

Keywords: Characteristics, Degradation, Photovoltaic, Rates of Degradation, Standard Conditions

\section{Introduction}

Photovoltaic solar energy is a form of renewable energy; it can generate electricity by converting the solar radiation and by using the photovoltaic effect [1].

The installation of photovoltaic systems is mainly dictated for optical performance by its geographical context as the location and conception of the sun exposure [2]. The performance and efficiency of photovoltaic modules are affected by several factors such as solar irradiation, ambient temperature, humidity, wind, shading and dust accumulation $[3,4]$; these factors can accelerate the degradation. Many studies have been focusing on the material and technological aspect of PV cells [5].

Module degradation and module failure are often present in PV system but not immediately recognized. The design system can frequently mask the effects of modules performance degradation and/or individual modules failure [6]. Technically, degradation mechanisms are important to understand because they may eventually lead to the failure of parameters. Typically, about $20 \%$ of decline is considered as failure, but there is no consensus on the definition of failure; 
because a high-efficiency module degraded at 50\%, may still has a higher efficiency than a non-degraded module from a less efficient technology [7].

Knowing that testing modules in laboratory are important, but it is also as important as conducting field-testing of PV systems to determine performance and degradation under actual operating conditions [8]. The main modes of PV modules degradation are identified in the literature, and the rate of degradation differs from one another according to the manufacturer, to technology, to the age, to the temperature, to the moisture, to the UV radiation and the place where the modules are installed [9].

This article presents the degradation evaluation of parameters performance such as characteristics I-V and P-V curves, maximum power $\left(\mathrm{P}_{\max }\right)$, open circuit voltage $\left(\mathrm{V}_{\mathrm{oc}}\right)$, short circuit current $\left(\mathrm{I}_{\mathrm{cc}}\right)$, fill factor $(\mathrm{FF})$ of a solar power plant installed of Center for Studies and Research on Renewable Energy (CERER) after several years of operation.

\section{Methodology}

\subsection{Modeling of Photovoltaic Cell}

A solar cell is traditionally represented by an equivalent circuit made of a power source, a diode, a resistance shunt/parallel $\left(R_{P}\right)$ and a resistance series. As shown in figure 1 , the electrical current available in the pile is modeled in this equivalent circuit well-known. The photovoltaic generator is neither a constant voltage source nor a source of current. It is modeled and described by the relationship between the current and the tension.

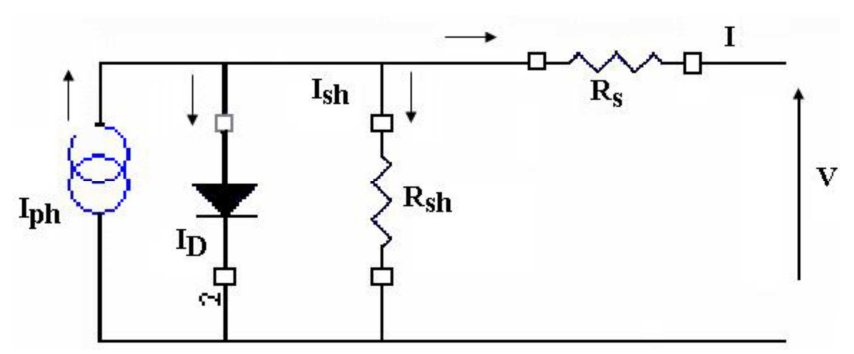

Figure 1. Equivalent circuit model of a PV cell.

Based on the equation of diode of Shockley, the mathematical model (characteristic I-V) for an individual cell statement is given as follows [10, 11, 12, 13].

$$
\mathrm{I}=\mathrm{I}_{\mathrm{ph}}-\mathrm{I}_{\mathrm{d}}-\mathrm{I}_{\mathrm{p}}=\mathrm{I}_{\mathrm{ph}}-\mathrm{I}_{\mathrm{o}}\left(\mathrm{e} \frac{\boldsymbol{V}+\boldsymbol{R} \boldsymbol{s} \boldsymbol{I}}{\boldsymbol{V t}}-1\right)-\frac{\boldsymbol{V}+\boldsymbol{I} \cdot \boldsymbol{R} \boldsymbol{s}}{\boldsymbol{R} \boldsymbol{p}}
$$

Where

$\mathrm{I}_{\mathrm{ph}}$ is the photocurrent (A); Io is the current of saturation of the diode (A); Rs is a series resistance $(\Omega) ; R_{P}$ is resistance shunt/parallel $(\Omega) ; \mathrm{V}_{\mathrm{t}}=\frac{n k T}{q}$ is the thermal tension; $\mathrm{n}$ is the factor of ideality of the diode; $\mathrm{q}$ is the electron charge. (1, $60 \mathrm{E}-19$ Coulomb); $\mathrm{K}$ is the Boltzmann constant $(1,381 \mathrm{E}-$ $23 \mathrm{~J} / \mathrm{K})$;

$\mathrm{T}$ is the temperature of the solar cell $(\mathrm{K})$.

\subsection{Presentation of the Experimental Platform}

\subsubsection{On-site Measure}

The experimental platform is installed in CERER (Center for Studies and Research on Renewable Energy). CERER is an University Institute located in the arrondissement of Hann Bel Air, on the edge of the ocean, in the Dakar region of Senegal. Senegal is located in the tropics, between $12^{\circ}$ and $16^{\circ} 841$ north latitude and $11^{\circ} 21$ and $17^{\circ} 32$ west longitudes. Senegal has a warm and sunshine season. Senegal has one of the solar potential resources, averaging $5,5 \mathrm{KWh} / \mathrm{m} 2 /$ day [14]. Senegal has a tropical climate with two seasons which difference is based on the rain. A dry season from November to May with temperatures are between $22^{\circ} \mathrm{C}$ and $30^{\circ} \mathrm{C}$, sometimes swept between December and February with a rather chilly wind. Then from June to October a rainy season prevails, the longest season in the south than in the north. Variations in relative humidity depend partly on the air temperature and humidity characteristics of air masses. The annual change on the relative humidity of the air is also tempered by the maritime influence and the annual average, is around $70 \%$. The highest values coincide with the rainy season and the lowest in April-May, and October to December-January.

\subsubsection{Data System}

The electronic load ESL-Solar 500 was especially developed to test crystalline and thin-film modules or module strings up to $5 \mathrm{~kW}$. All essential load tests of solar modules can be realized with the ESL-Solar 5000. The load can be operated via ESolar Software on the integrated Notebook.

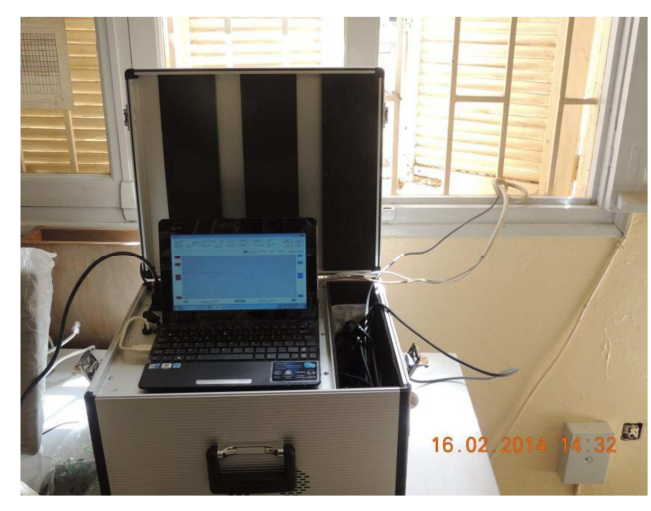

Figure 2. Data Acquisition.

The datas acquired by the MPP Track or scan, can be read through a data acquisition card inserted on the interface. Voltage, current and power are visualized on the screen of the notebook. In order to gain an exact power curve, voltage and current are measured simultaneously. The ESL-Solar 5000 is useful for the installation of a solar plant, the maintenance service and measurement and checks of single solar modules. The ESL-Solar 5000 is mounted in a portable suitcase. Also all necessary accessories as cables and the sensor are placed inside the suitcase.

Technical specifications used for outdoor characterization are given in the following table 1 . 
Table 1. Technical specifications of acquisition system.

\begin{tabular}{lll}
\hline Reference & Maximum Rating & Values \\
\hline & Measurement Light Intensity & 0 to $1200 \mathrm{~W} / \mathrm{m}^{2}$ \\
& Measurement temperature & $-20^{\circ} \mathrm{C}$ to $+80^{\circ} \mathrm{C}$ \\
ESL-Solar 5000 & Power (max3s) & $5000 \mathrm{~W}$ \\
& Input voltage & 0 to $800 \mathrm{~V} \mathrm{DC}$ \\
& Current & 0 to $20 \mathrm{~A} \mathrm{DC}$ \\
\hline
\end{tabular}

curves) can be scanned [15]. The datas of the parameters modules will be used for calculation of the STC (standards test conditions) estimated values. For obtain their datas, you do enter the specifications data from the technical documentation of the module. You can also enter the datas from a reference module, which was tested with a flash tester under standard test conditions.

With the ESolar software vi-curves (voltage-current-
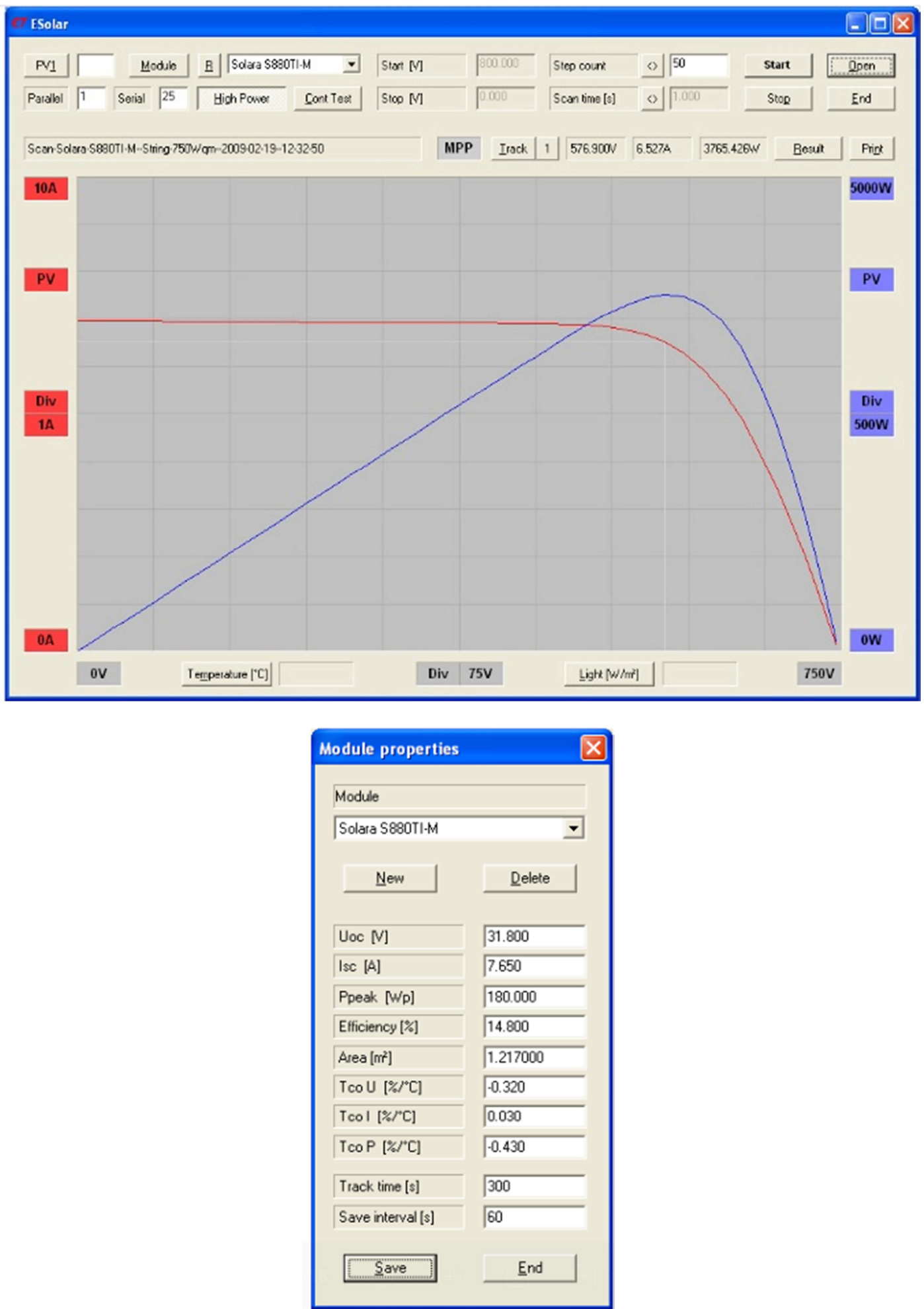

Figure 3. Configuration window electrical parameters of the tested modules. 


\subsubsection{Presentation of Solar Plan}

The modules formed together a generator of a nominal output of $3,15 \mathrm{kWc}$ of a system connected with the network. The power station is installed since 2012 in CERER. Geographical datas of the site of CERER have been given in section 2.2.1.

The field of the system is presented in Figure 3. It is composed of eighteen modules connected in series-. Its configuration is made as the shape of a parking cars which is a space arranged especially for the parking of the cars (Figure 2).

This installation doesn't only make possible the injection on the network the produced energy, but also it is able to function autonomously when the network is broken down (back-up system).

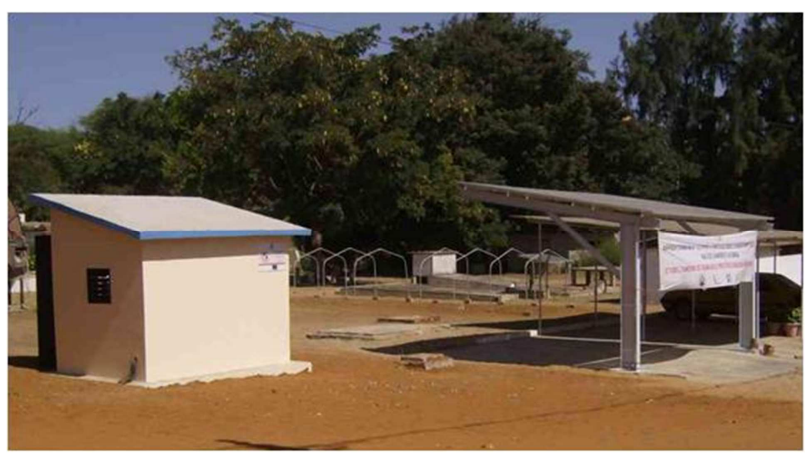

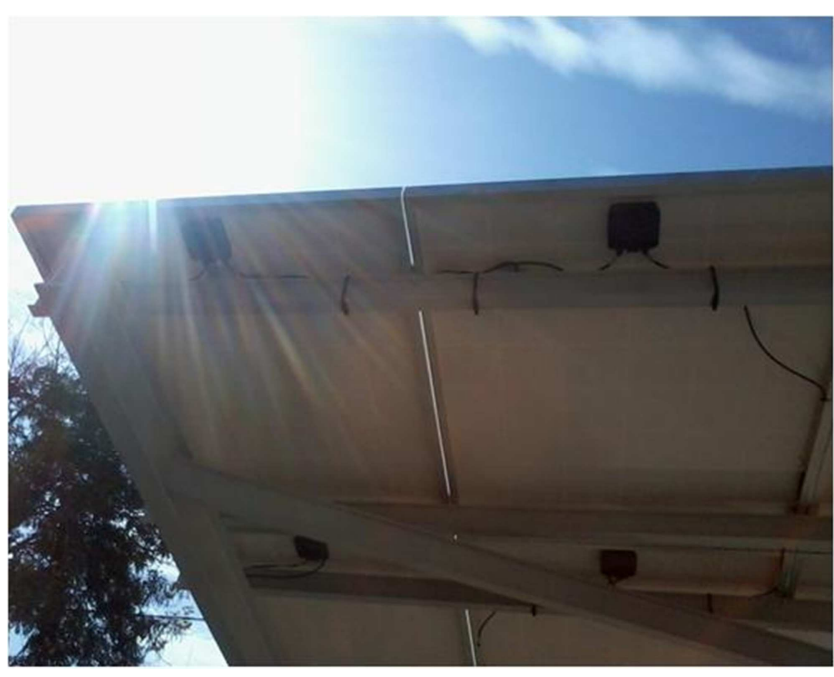

Figure 4. Power station.

The performances of the modules are given in the table 2 . Oriented to the southern full position, the modules are tilted horizontal plane according to the latitude of the place. They all are identical characteristics of type Stp175p-1 which the basic semi material conducting is the polycrystalline.

Table 2. Parameters of modules given by the manufacturers.

\begin{tabular}{lllll}
\hline Technology & Manufacturer & Reference & Parameters & Values \\
\hline & & Maximum output power $\left(\mathrm{P}_{\max }\right)$ & $175 \mathrm{Wc}$ \\
Polycristalline & & & Maximum output intensity $\left(\mathrm{I}_{\max }\right)$ & 7,55 Ampères \\
Silicon & \multirow{3}{*}{ STER } & & Maximum output voltage $\left(\mathrm{V}_{\max }\right)$ & 23,1 Volts \\
& & Short circuit current $\left(\mathrm{I}_{\mathrm{cc}}\right)$ & 8,19 Ampères \\
& & & Open circuit voltage $\left(\mathrm{V}_{\mathrm{co}}\right)$ & 29,5 Volts \\
\hline
\end{tabular}

\subsection{Diagramme of Methodology}

Research has shown that degradation of photovoltaic modules has become a recurrent phenomenon. Manufacturers of modules focus on developing mainly new technologies without worrying about the state of operation of the devices realized in the field. Our study is described according to the given scheme.

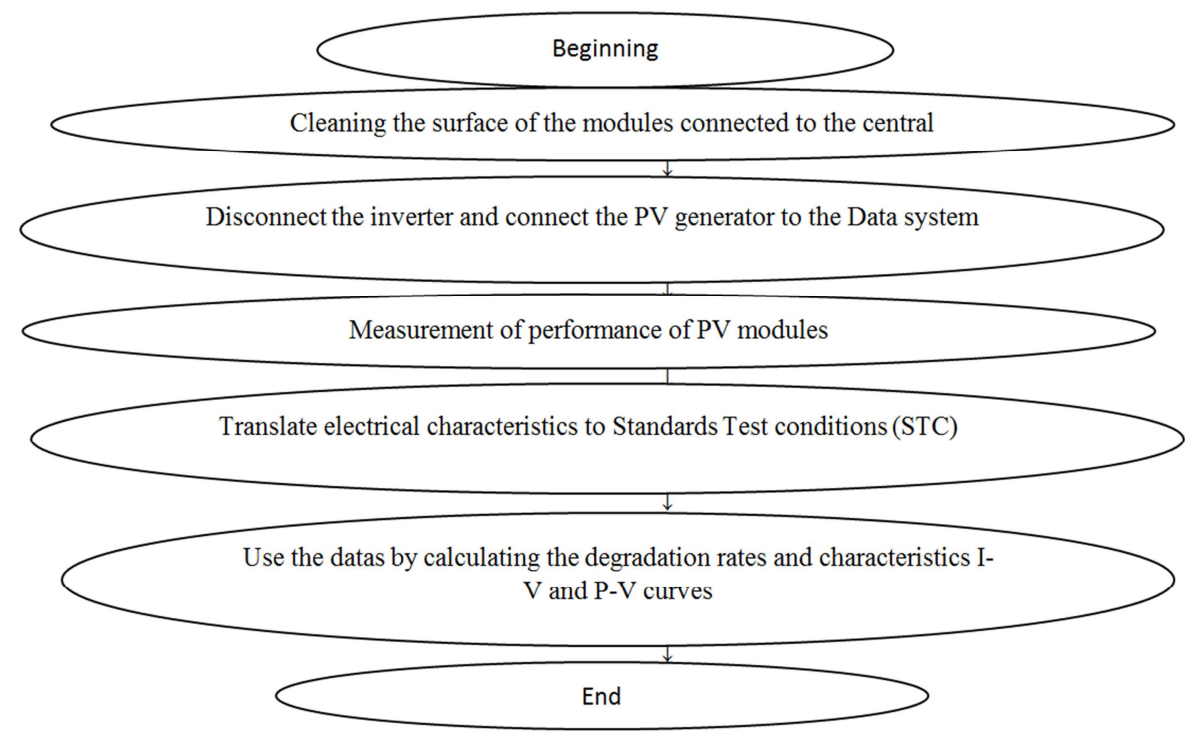

Figure 5. Methodology diagram. 
The modules are tested at ambient conditions corresponding to an ambient temperature being at $19.9^{\circ} \mathrm{C}$, to relative humidity of $80.8 \%$ and with a light intensity $817 \mathrm{~W} / \mathrm{m}^{2}$.

This system doesn't only allow of acquiring the measurements in real time by displaying them on the computer screen but also it saves them to provide a database for further processing.

\section{Results and Discussions}

\subsection{Analysis and Evaluation of Degradation}

\subsubsection{Analysis of Degradation}

The work of identifying the degradation mechanisms in the system and of establishing their degradation rate has become increasingly important. An handful number of researches have worked on different methods of measurement used in order to identify failure characteristics $[3,16,17,18,19,20$, 213.1.2. Calculation of Degradation

To evaluate the degradation of individual module or of an entire system after several years of exposition, it is imperative to determine the degradation rate $\left(R_{D}\right)$ and the annual degradation rate $\left(\mathrm{R}_{\mathrm{DA}}\right)$ of each parameter [22, 23, 24]. Expression of the degradation rate is analytically given by the following equations:

$$
R_{D}(Z)(\%)=\left(\frac{Z 0-Z}{Z 0}\right) \times 100
$$

Where

$\mathrm{Z}_{0}$ is defined as the initial state and $\mathrm{Z}$ the state at time $\mathrm{T}$ of modules parameters as maximum output current $\left(\mathrm{I}_{\max }\right)$, Maximum output voltage $\left(\mathrm{V}_{\max }\right)$, maximum power $\left(\mathrm{P}_{\max }\right)$, open circuit voltage $\left(\mathrm{V}_{\mathrm{oc}}\right)$, short circuit current $\left(\mathrm{I}_{\mathrm{sc}}\right)$ and fill factor under Standard Test Condition in the initial state and after four years of operation respectively.

Thus knowing the number of years of operation $(\Delta t)$, we can deduce the annual degradation rate which is given by the equation (3).

$$
\mathrm{R}_{\mathrm{DA}}(\mathrm{Z})(\%)=\frac{R D(Z)(\%)}{\Delta t}
$$

\subsection{Degradation of I-V and P-V Curves}

In this work the evaluation of photovoltaic module performance is based on the measurement of performance parameters such as maximum power, maximum current, maximum voltage, short circuit current, open circuit voltage, fill factor, and experimental I-V and $\mathrm{P}-\mathrm{V}$ characteristics curves.

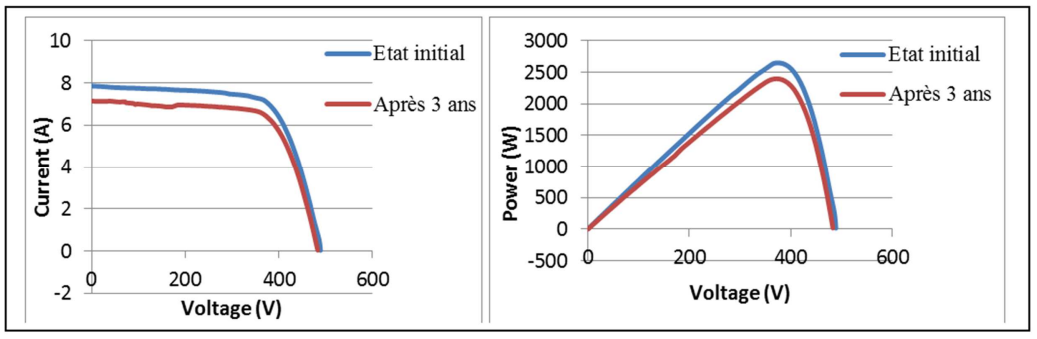

Figure 6. Characteristics $I-V$ and $P-V$ in real conditions.

Thus, the measurements of I-V characteristics must be corrected to Standards Test Conditions by using the following equations (4) and (5) [25, 26].

$$
\begin{gathered}
\mathrm{I}_{\mathrm{STC}=} \mathrm{I}_{\mathrm{m}} \times\left(\frac{G s t c}{G m}\right)+\alpha\left(\mathrm{I}_{\mathrm{STC}}-\mathrm{I}_{\mathrm{m}}\right) \\
\mathrm{V}_{\mathrm{STC}}=\mathrm{V}_{\mathrm{m}}-\mathrm{R}_{\mathrm{S}}\left(\mathrm{I}_{\mathrm{STC}}-\mathrm{I}_{\mathrm{m}}\right)-\mathrm{K} \cdot \mathrm{I}_{\mathrm{STC}}\left(\mathrm{T}_{\mathrm{STC}}-\mathrm{T}_{\mathrm{m}}\right)+\beta \cdot\left(\mathrm{T}_{\mathrm{STC}}-\mathrm{T}_{\mathrm{m}}\right)(5)
\end{gathered}
$$

Where $\mathrm{I}_{\mathrm{STC}}, \mathrm{V}_{\mathrm{STC}}, \mathrm{G}_{\mathrm{STC}}, \mathrm{I}_{\mathrm{m}}, \mathrm{V}_{\mathrm{m}}, \mathrm{G}_{\mathrm{m}}$ represent the values of current $(\mathrm{A})$, voltage $(\mathrm{V})$ and irradiance $\left(\mathrm{W} / \mathrm{m}^{2}\right)$ respectively in the Standards Test Conditions (STC) and those measured in real conditions operational;

$\alpha$ and $\beta$ represent the current and voltage temperature coefficients;

$\mathrm{R}_{\mathrm{S}}$ is the series resistance;

$\mathrm{K}$ is a curve correction factor.

Measures in the STC are given to a light intensity of $1000 \mathrm{~W} / \mathrm{m}^{2}$ and a temperature of $20^{\circ} \mathrm{C}$.

by using the translational equations (Eq. (4)) and (Eq. (5)) we will obtain the characteristic degradation I-V and P-V curves at Standards Test Condition Figure 7.
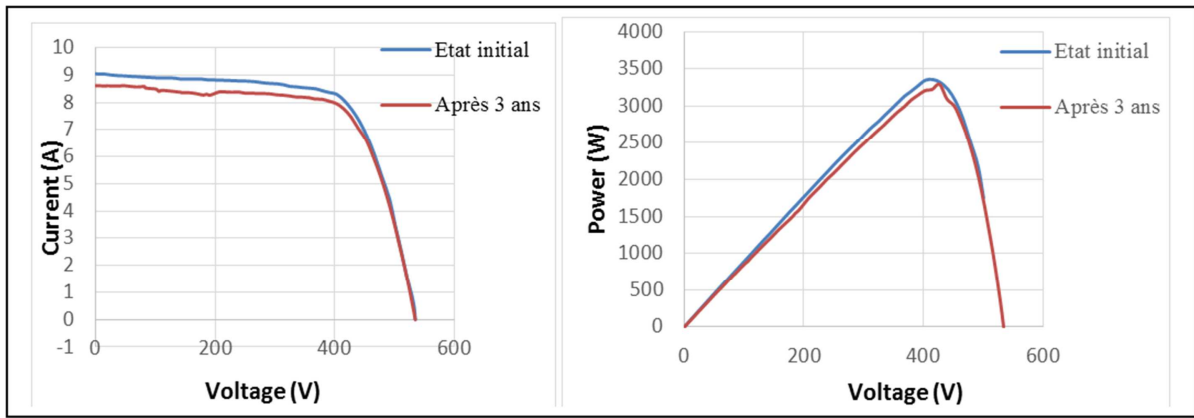

Figure 7. Characteristics I-V and P-V at Standard Test Conditions. 
In general, the characteristics of the modules are given in the conditions of actual operation that are different from those given by the manufacturers in the standards test condition as shown in Figure 6 and 7.

In terms of actual operation, the maximum power of the system was worth $2650.124 \mathrm{~W}$ in the initial state. This value fell during the 3.3 years of operation till $2304.909 \mathrm{~W}$.

Looking at these graphs, we can see a large difference between the carried out experimental feature and the obtained translated characteristics. What may be considered as logical because many factors affect the characterization of modules performed under two different conditions. This gap can be from the modules temperature change, the sunlight and among others. In both cases, there is a decrease parameter system over time being, in actual operation or standard test conditions. But for better visibility degradation, we will be interested in the parameters transmitted in the STC (table 3)

\subsection{Degradation of Performance Parameters}

The electrical parameters of modules after several years of operation are presented in the table 3. It shows the decrease of parameters under Standards Test Condition (STC). Parameters degradation were determined by using the equation from (Eq. (2)) for the global degradation and from (Eq. (3)) for the degradation rate for each parameter such as $\mathrm{P}_{\max }, \mathrm{V}_{\max }, \mathrm{I}_{\max }, \mathrm{V}_{\mathrm{oc}}, \mathrm{I}_{\mathrm{sc}}$ and $\mathrm{FF}$. These results are extracted from the study of an entire system.

Table 3. Variation parameters of modules after several years' operation.

\begin{tabular}{lllll}
\hline Parameters & Initials values & Actual values & $\mathbf{R}_{\mathbf{D}}(\%)$ & \\
\hline $\mathrm{P}_{\max }(\mathrm{W})$ & 3356,84 & 3133.57 & 6.65 & \\
$\mathrm{~V}_{\max }(\mathrm{V})$ & 415.81 & 392.61 & 5.57 & 2.01 \\
$\mathrm{I}_{\max }(\mathrm{A})$ & 8,07 & 7.98 & 1.13 & 1.69 \\
$\mathrm{~V}_{\text {oc }}$ (V) & 534.49 & 534.05 & 0.08 & 0.34 \\
$\mathrm{I}_{\text {sc }}(\mathrm{A})$ & 9.04 & 8.72 & 3.63 & 0.02 \\
$\mathrm{FF}(\%)$ & 69.40 & 67.28 & 3.05 & 1.10 \\
\hline
\end{tabular}

After a period of 3.3 years of operation, the characteristics of the module have undergone a remarkable decrease of theirs parameters. Their annual degradation rates are estimated at $2.01 \%$ / per year, $1.69 \%$ per year, $0.34 \%$ per year, $1.10 \%$ per year and $0.92 \%$ per year respectively for maximum power $\left(\mathrm{P}_{\max }\right)$, maximum voltage $\left(\mathrm{V}_{\max }\right)$, maximum current $\left(\mathrm{I}_{\max }\right)$, short circuit current $\left(\mathrm{I}_{\mathrm{sc}}\right)$ and fill factor $(\mathrm{FF})$ (table 3). When we talk about degradation of interest point is the maximum power point.

Thus, the degradation rate of the maximum power of this global system is important equivalent to $2.015 \%$ per year. This value is in accordance with the study conducted by Ababacar and al. [26] and which results are estimated at $1.62 \% /$ year and $2.96 \%$ /year. The studies are individually based on two polycrystalline modules corresponding respectively on the exposure period of 3.4 and 4 years.

Quintana and al [27] studied the increased degradation rate for a global system in relation with the degradation of each PV module Natural Bridges National Park PV System in Utah, USA. From this result, they found that the rate degradation of each module was $0.5 \%$ per year; while the system of degradation rate was equivalent to $2.5 \%$ per year. Thus the degradation rate of global system is higher than the individual one.

In addition, Berman and Faiman [28] found a rate degradation to $1.3 \%$ after 3.4 years of operation of polycrystalline PV modules in Arizona.

Degradation varies according to season, time and depends on environmental parameters. Osterwald and al [29] just confirm that hypothesis: from this study in two monocrystalline and two multicrystalline modules, they found that the rapid initial degradation was attributed to oxygen contamination in the bulk of the Si junction, whereas the slow long-term degradation was correlated linearly with ultraviolet exposure.

Despite the progress achieved in the last decade, several interesting questions, such as the linearity and the precise impact of climate have not been satisfactorily answered that what concluded Jordan and al [30].

\section{Conclusion}

The study is an evaluation of the degradation of a global system after few years of operation. The experimental study was conducted in the Center of Studies and Research on Renewable Energies, on the solar PV plant. The central PV made of 18 modules connected in series. The annual degradation rate of the total electrical parameters system, estimated at $2.01 \%$ / year, $1.10 \%$ / year and $0.92 \%$ / year and respectively for the maximum power (Pmax), the short- Circuit (ISC) and the form factor (FF), is important however the open circuit voltage (VOC) noted $0.02 \%$ / year showing no significant variation. So this study is based on the analysis of the overall system consisting of the serial connection of the 18 modules. The actual results allow us to conclude that variations in the performance characteristics of the PV system deteriorate over time. Therefore, our PV modules do not maintain their initial performance and several factors such as exposure to radiation, moisture, dust accumulation etc. may be the causes of the fall in performance of this system. Otherwise, this study opens up perspectives on the real causes of such degradation.

\section{References}

[1] M. A. Quintana and D. L. King, T. J. McMahon and C. R. Osterwald, Commonly Observed Degradation In Field-Aged Photovoltaic Modules 
[2] Monto Mani, Robot Pillai, Impact of dust on solar photovoltaic (PV) performance: Research status, challenges and recommendations, Renewable and Sustainable Energy Reviews; 14(2010):3124-3131

[3] E. Kaplani, Detection of Degradation Effects in Field-Aged CSi Solar Cells through IR Thermography and Digital Image Processing, International Journal of Photo energy volume 2012, Article ID 396792, 11 pages

[4] Ababacar Nd., Abderafi Ch., Abdessamad K., Cheikh M. F. K., Pape A. Nd., Vincent S.; Degradation of silicon photovoltaic modules: A literature review, Solar Energy 96 (2013):140-151

[5] Farid. A. T, Mohammed. A. Al. H and Hamdy. J. B, Study of the Effects of Dust, Relative and Temperature on solar PV Performance in Doha: Comparison Between Monocrystalline and Amourphous PV, International Journal of Green Energy, 10: 7, 680-689

[6] Nicoleta. S-H, Kris. D, Albert. L. V, Sarah. K, Dirk. J, Comparative Study of the Performance Of Field-Aged photovoltaic Modules Located In a hot and Humid Environment National Renewable Energy 2376-2381; 2011

[7] Dirk C. J and Sarah. R. K, Photovoltaic Degradation Rate - An Analytical Review, National Renewable Energy Laboratory, 2012

[8] B. H. King, J. EGranata and A. J. Luketa-Hanlin, System Long Term Exposure Program: Analysis of the First Year of Data, Sandia National Laboratories, Albuquerque, NM 87185

[9] Macben. M, Nelson. T, Mutua. B, Ismael. A, Degradation Prevalence Study of Field-Aged Photovoltaic Modules Operating Under Kenyan Climatic Conditions; Science Journal of Energy Engineering 2015; 3(1):1-5

[10] E. Lorenzo, Solar Electricity: Engineering of Photovoltaic System, Progensa, Sevilla, 1994

[11] V. Badescu, Single Optimization Procedure for Silicon-Based Solar Cell Interconnection in a Series-Parallel PV Module, Energy Conversion and Management, Vol47, $\mathrm{N}^{\circ}$ 9-10, pp1146-1158, 2006

[12] W. De. Soto, S. A. Klein and A. Beckman, Improvement and Validation of a Model for Photovoltaic Array Performance, Solar Energy, vol 80, 78-88, 2006

[13] Tao. Ma, Hongxing. Y, Lin Lu, Development of a model to simulate the performance characteristics of crystalline silicon photovoltaic modules/strings/arrays, Renewable Energy Research Group, Solar Energy 100(2014), 31-41

[14] http://www.Senegal-energies.com/index php/potentiel-solaire

[15] https://www.dropbox.com/sh/u06shijn892o0ym/AACyLpblFl miXah9byQ9IpQua/et/Do umentation/Manual-ESL-Solar5000-R5-eng.pdf?dl=0

[16] Twu-Kei Wen, Ching-Chung Yin, Crack detection in photovoltaic Cells by interferometric analysis of electronic speckle patterns, Solar Energy Material and Solar Cells 98 (2012) 216-223

[17] Gordon R. Mon ${ }^{+}$, R. J. Rose, Jr Electrochemical degradation of amorphous-silicon Proceedings of the 18th IEEE
Photovoltaic Specialists Conference Las Vegas, Nevada, October 21-25, 1985

[18] C. Peike, S. Hoffman, K-A. Weib, N. Bogdanski, M. Kohl, PV module degradation in the field and in the lab-how does it fit together?, Presented at the $29^{\text {th }}$ European PV Solar Energy Conference and exhibition, 22-26 September 2014, Amsterdam, The Netherlands

[19] B. Mitchell, J. W. Weber, M. Juhl, D. Macdonald, T. Trupke, Photoluminescence Imagin of silicon Bricks, Solid State Phenomena Vols.205-206 (2014), pp 118-127

[20] Gordon R. Mon ${ }^{+}$et al, Predincting Electrochemical Breakdown in Terrestrial photovoltaic module, Proceeding of the $17^{\text {th }}$ IEEE Photovoltaic Specialists Conference Orlando, Florida, May 1-4, 1984

[21] Radesk. S, Jiri. V, Martin. M, Progression of silicon Solar Cells Luminescence Diagnostic Methods Universal Journal of Electronic Engineering 2(1): 18-22, 2014

[22] Sadok. M, A. Mehdaoui, Outdoor testing of photovoltaic array in the Saharan region, Renewable Energy 2008; 33:2516-24

[23] Ahmad. B, Messaoud. H, Abdelkader. Ch, Mohammad. M, Salal. L, Mohammed. S, Nadir. B, Mourad. O. Ahoui. I, Analysis and evaluation of the impact of climatic conditions on the photovoltaic modules performance in the desert environment, Energy Conversion and Management 106(2015), $1345-1355$

[24] M. Sadok, B. Benyoucef et A. Mehdaoui, Performance et dégradation des modules en milieu saharien, Revue des Energies Renouvelables SIENR 12 Ghardaïa 2013-2012

[25] Emad. A. S, E. T. El Shenawy, Abd. El-Shafy. A. Nafeh, Effect of Different Dust Accumulation on the Performance of PV Module in Egypt, International Journal of Advanced Information Science and Technology vol.44 $\mathrm{N}^{\circ} .44$, December 2015

[26] Ababacar Nd, Cheikh M. F. Kebe, Abderafi. Ch., Papa. A. Nd, Vincent. S, Abdessamad. K, Degradation evaluation of crystalline-silicon photovoltaic modules after a few operation years in a tropical environment Solar Energy 103(2014) 70-77

[27] Quintana MA, King DL, Hosking FM, Kratochvil JA, Johnson RW, Hansen BR, Dhere NG, Pandit MB. Diagnostic analysis of silicon photovoltaic modules after 20-year field exposure. Proceedings of the 28th PV Specialists Conference, Anchorage, AK, USA, 2000; 1420-1423. DOI: 10.1109/PVSC.2000.916159

[28] Berman D, Faiman D. EVA browning and the time dependence of I-V curve parameters on PV modules with and without mirror-enhancement in a desert environment. Sol Energy Mat Sol Cells 1997;45:401-12

[29] Osterwald CR, Anderberg A, Rummel S, Ottoson L. Degradation analysis of weathered crystalline-silicon PV modules. Proceedings of the 29th PV Specialists Conference, New Orleans, LA, USA, 2002; 1392-1395. DOI: 10.1109/PVSC.2002.1190869

[30] Dirk C. Jordan and Sarah Kurtz Photovoltaic degradation rates - An analytical review, Progress in Photovoltaics: Research and application NREL/JA-5200-51664 June 2012 